Cronfa - Swansea University Open Access Repository

This is an author produced version of a paper published in :

Modern Language Review

Cronfa URL for this paper:

http://cronfa.swan.ac.uk/Record/cronfa19969

\title{
Paper:
}

Rothwell, A. (2015). 'qui es-tu sous la ressemblance qui va là sous couvert de moi' - the hourglass of poetic identity in Bernard Noël's L'Ombre du double. Modern Language Review, 110(1), 121-148.

This article is brought to you by Swansea University. Any person downloading material is agreeing to abide by the terms of the repository licence. Authors are personally responsible for adhering to publisher restrictions or conditions. When uploading content they are required to comply with their publisher agreement and the SHERPA RoMEO database to judge whether or not it is copyright safe to add this version of the paper to this repository. http://www.swansea.ac.uk/iss/researchsupport/cronfa-support/ 


\title{
Offprinted from
}

\author{
MODERN LANGUAGE REVIEW \\ VOLUME 110, PART 1 \\ JANUARY 2015
}

(c) Modern Humanities Research Association 2015 


\section{'QUI ES-TU SOUS LA RESSEMBLANCE | QUI VA LÀ SOUS COUVERT DE MOI': THE HOURGLASS OF POETIC IDENTITY IN BERNARD NOËL'S 'L'OMBRE DU DOUBLE'}

A popular encyclopedia from the mid-nineteenth century contains the following definition:

Sablier. (Marine.) C’est un instrument formé de deux petites bouteilles ou ampoulettes, dont les goulots en entonnoir sont réunis; elles contiennent une certaine quantité de sable très-fin qui, en tombant d'une ampoulette dans l'autre, sert à mesurer le temps. Cet instrument était d'un usage universel avant l'invention des horloges; et les anciens [...] ont représenté le temps portant un sablier d'une main et une faux de l'autre. ${ }^{2}$

In a previous article I traced the image of the sablier from its explicit appearance in Bernard Noël's early poetry of the body (the textual contre-corps) through to a largely implicit presence in his later work, as the figure governing a phenomenological relationship between inner (mental) and external spaces, and then between mind and text. ${ }^{3}$ I argued that what makes the hourglass poetically productive for Noël, beyond its symbolic associations with mortality and the 'sands of time', are the figural possibilities of its physical configuration. Made up of two identical transparent chambers which communicate via a constriction through which passes a granular substance, the sablier is a dual and parallel structure designed to be inverted, its contents flowing backwards and forwards with equal ease. Whether its two ampoules are configured metaphorically to represent body and mind, mind and world, or mind and page, for Noël the key property of the sablier is that it allows the transfer of material between conventionally unconnected domains, working against the conceptual and linguistic dualism that has structured Western thought since its origins. As I concluded in the earlier article, the hourglass offers a potent figure of poetic creativity, showing how 'grains' of meaning can switch value to produce unfamiliar, challenging conceptualizations. Even when it is not thematized explicitly, its attributes of parallelism, equivalence,

${ }^{1}$ Bernard Noël, 'L'Ombre du double', in Extraits du corps [henceforth EC] (Paris: Gallimard, 2006), pp. 217-65 (p. 259).

${ }^{2}$ Auguste Wahlen [i.e. Jean-François-Nicolas Loumyer], Nouveau dictionnaire de la conversation; ou, Répertoire universel de toutes les connaissances nécessaires, utiles ou agréables dans la vie sociale [...] sur le plan du Conversation's Lexicon [. . .], 25 vols (Brussels: A la Librairie Historique-Artistique, 1842-45), xxIv (1844), 70. The entry explains that two types of hourglass were used on ships at that time: 'celui de demi-heure et celui de demi-minute' (emphasis original). The first measured the watches: each time the sand ran out a bell was sounded, the glass was turned, and after eight bells the watch changed over; the second established speed, timing the paying out over the stern of a knotted rope with a plank (loch) on the end.

3 Andrew Rothwell, “"et ma logique va en rond": Bernard Noël's Hourglass Figure', $M L R, 108$ (2013), 109-28. 
and invertibility are found at work throughout the fabric of Noël's poetry. The present article extends that analysis to examine how the sablier constructs textual selfhood and the poetic persona, with particular reference to the 1993 poem cycle 'L'Ombre du double'. ${ }^{4}$

As I suggested previously, the sablier offers a figural template for Bernard Noël's phenomenological view of perception, a tool for constructing poetically the relationship between self and world. In the epigraph to Journal $d u$ regard (1988), his friend the artist Olivier Debré defines this phenomenological exchange through which external phenomena become mental concepts in both spatial and semantic terms:

L'idée de l'espace et le comportement de l'homme sont toujours liés... L'homme se réfléchit dans l'espace et l'espace conçu le façonne en retour...5

Commenting on this statement, Philippe Païni stresses the dialectical and reciprocal exchange with the external world that the gaze mediates, simultaneously engaging the observer in activities of both introspection and projection-as if reality were holding up a mirror to the mind, but a mutable one in which both parties undergo influence and change:

C'est une traversée du miroir, une traversée du regard, qui a lieu tout le temps. Un aller-retour permanent, où le retour n'est jamais le contraire de l'aller. On ne vit pas l'aller, on ne vit pas le retour. On vit l'aller-retour. Et le regard est le lieu du passage par lequel se mentalise le dehors, par lequel aussi se réfléchit le mental - en passant par dehors. ${ }^{6}$

This reflexive relationship between world and mind is given literal, geometrical expression in 'La Moitié du geste' (1982), where Noël constructs a phenomenological and alliterative sablier of two parallel spheres communicating via the gaze:

et le regard

qui ramène la ronde

terre en tête ${ }^{7}$

\footnotetext{
4 Bernard Noël, L'Ombre du double: poèmes (Paris: P.O.L., 1993), pp. 7-67, which also contains 'Quel est ce visage' and 'Sur le peu de corps', designated 'II' and 'III' respectively. The present article will refer to the republication in $E C$, and will not discuss in detail parts II and III, also reprinted there.

5 Bernard Noël, Journal du regard (Paris: P.O.L., 1988), p. 7. Compare: 'Mais le mental, dis-je soudain, n'est-ce pas le retournement du visible? l'envers du miroir?' (Bernard Noël, Le 19 octobre 1977 (Paris: Flammarion, 1979), p. 129).

${ }^{6}$ Philippe Païni, 'Le Corps écrit - Avec Bernard Noël', in Avec Bernard Noël toute rencontre est l'énigme, ed. by Serge Martin (La Rochelle: Himeros Rumeur des Âges, 2004), pp. 61-8o (p. 64).

7 Bernard Noël, La Chute des temps [henceforth CT] (Paris: Gallimard, 1993), pp. 107-65 (p. 154). The converse process, with the gaze located in the external world, is also conveyed in a sablier image in 'Grand arbre blanc' (1966): 'mais si creuse est la nuit | que l'on voudrait grandir | grandir | jusqu’à remplir ce regard sans paupière' (EC, p. 62).
} 
This relationship is figured in the closing lines of the cycle as explicitly specular, with mental space mimetically resembling external reality:

mais la grandeur du monde

a créé notre tête

par désir d'un miroir

(CT, p. 165)

At the same time, however, it involves an exchange of characteristics which, as Noël states in another sablier construction earlier in the same cycle, are intimately constitutive of, and modify, selfhood:

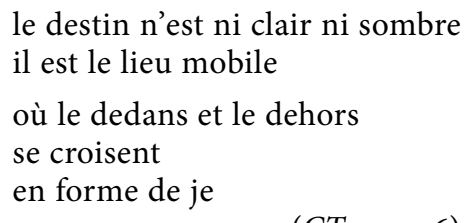

- 'se croisent' both spatially and genetically, in the sense of hybridization, cross-breeding, or exchange of characteristics. Again, the mirror offers a transparent but also troubling materialization of this double croisement, constructing behind its surface a virtual spatial analogue of reality (though with the variation of lateral inversion) in which the observer can see himself seeing and becoming, in a potentially infinite mise en abyme of identity.

This specular quality of identity is beautifully captured in the poem 'Les États de l'air' (1982), dedicated to Brazilian artist Vieira da Silva:

$$
\begin{aligned}
& \text { miroir vous êtes } \\
& \text { notre tête au-delà } \\
& \text { on y rentre chez soi } \\
& \text { par la pupille } \\
& \text { cette petite lune noire }
\end{aligned}
$$

In this compressed figure, the reflected head is not a two-dimensional image, but rather an interior space (his own mentality) which the observer can enter and which 'contains' a negative version of external reality, figured by the white/black inversion of the moon/pupil. In 'Poème à déchanter' (1968) the mirror is a space of potential, paradoxical identity:

$$
\begin{aligned}
& \text { le miroir } \\
& \text { le miroir parle toujours moi }
\end{aligned}
$$

${ }^{8}$ Bernard Noël, Les Yeux dans la couleur (Paris: P.O.L., 2004), pp. 29-32 (pp. 30-31). See also my commentary 'Bernard Noël: "Les États de l'air"', in Twentieth-Century French Poetry: A Critical Anthology, ed. by Hugues Azérad and Peter Collier (Cambridge: Cambridge University Press, 2010), pp. 222-29. 
et je

c'est le visage sans visage

illisible

$$
(E C, \text { p. } 100)^{9}
$$

This empty but inherently dialogical space, which here doubly negates rather than affirms the terms of the moi/je relationship, is one into which, in ' $\mathrm{La}$ Moitié du geste', the gaze feels drawn, to seek, recognize, and look into itself in a gesture of extreme vulnerability and self-doubt:

$$
\begin{aligned}
& \text { quelque chose } \\
& \text { à peine quelque chose } \\
& \text { du presque blanc } \\
& \text { l'œil cherche l'œil } \\
& \text { en lui-même } \\
& \text { précairement } \\
& \text { et désarmé } \\
& \text { je suis } \\
& \text { attendant } \\
& \qquad C T, \text { p. 155) }
\end{aligned}
$$

The final verb of existential identity is undermined rather than affirmed by its homonym, leaving the je only able to observe his ambivalent identity from a hesitant distance. This pervasive self-doubt turns into alienation in 'L'Ombre du double', which conducts a sustained forensic deconstruction of the poetic persona using the mirror sablier ('l'œil cherche l'œil') with a depth and figural complexity probably unequalled in contemporary poetry.

\section{'Maison d'envers', 'tête d'ombre'}

'L'Ombre du double' is a substantial poem cycle divided into five numbered 'séquences' comprising respectively nine, seven, nine, nine, and nine texts, each nine lines long (a single opening line followed by four groups of two). Each sequence except the second divides into three sets of three poems, making a total of fifteen sets (in the second sequence the third set contains just a single poem), and each set opens with a question ('qu'est-ce que...') which 'generates' the rest of the set in response. Thus, as frequently happens in Bernard Noël's work, the textual fabric is conditioned by a pre-existing structure of numerical and rhetorical constraints, a prepared space or blank

9 Observing artist Roman Opalka (1931-2011) at work in 1990, Noël notes his comment: 'cette toile c'est un miroir où tu vois l'infini un miroir n'a pas de couleur c'est nous qui donnons la couleur aux miroirs' (Bernard Noël, Le Roman d'un être (Paris: P.O.L., 2012), p. 79; first published as 'Détails d'Opalka', in Christine Savinel, Jacques Roubaud, and Bernard Noël, Roman Opalka (Paris: Dis Voir, 1996)). 
thematic map into which the mental material of the poetry will 'precipitate'. ${ }^{10}$ The generating matrix of questions embraces universal lyrical themes (life, death, love, and time), but also some perhaps less expected abstractions (mystery, objectivity, will, reason, appearance), and those two key attributes of the Noélian poetic sablier, seeing and speaking:

Séquence 1: 'qu'est-ce que le temps' ( $E C$, p. 219), 'qu'est-ce que le mystère' (EC, p. 222), 'qu'est-ce que la vue' (EC, p. 225)

Séquence 2: 'qu'est-ce que le face à face' ( $E C$, p. 229), 'qu'est-ce qu'un visage' ( $E C$, p. 232), 'qu'est-ce que la vie' (EC, p. 235)

Séquence 3: 'qu'est-ce qui nous fait vivant' (EC, p. 237), 'qu'est-ce que la mort' ( $E C$, p. 240), 'qu'est-ce que l'objectivité' (EC, p. 243)

Séquence 4: 'qu'est-ce que la volonté' (EC, p. 247), 'qu'est-ce que le miroir' (EC, p. 250), 'qu'est-ce que la raison' (EC, p. 253)

Séquence 5: 'qu'est-ce que l'amour' (EC, p. 257), 'qu'est-ce que l'apparence' ( $E C$, p. 260), 'qu'est-ce que la parole' (EC, p. 263)

Perhaps the unifying thematic focus of the whole cycle, however, is the question of identity itself, articulated in the second sequence in terms of self-other ('qu'est-ce que le face à face') and self-self ('qu'est-ce qu'un visage') relations. Connecting this armature of questions into a single thematic programme is an underlying concern with the identity and expressive capacity of the poetic persona: who is he, and what allows him to speak? At the heart of these questions lies the figural sablier of the mirror.

Perhaps unexpectedly, the opening poem of the cycle introduces the mirror in response to a question about time, rather than space, on which the whole cycle turns:

qu'est-ce que le temps
tu manges le papier
la bouche s'efface
tu fermes la fenêtre
pour compter l'air
un reflet se lève
un corps d'en face
le tu d'un toi
le contre visage

(EC, p. 219)

In narrative terms the poetic persona, self-referring here as $t u$, closes a window to shut off inside from outside space and 'air', and sees in it a defamiliarized reflection-as the opening poem of the second sequence makes clear, it is

${ }^{10}$ See the Introduction to my bilingual edition of Bernard Noël, La Chute des temps/Timefall (Halifax, NS: VVV Editions, 2006), especially pp. 18-25. 
dark outside ('la nuit est un miroir | où le tu met une aile au toi', $E C$, p. 222). ${ }^{11}$ Described as a (spatially) opposite body and a 'contre visage', this virtual alter ego invites comparison with the contre-corps which, in the early poetry, Noël aspired to create through writing. ${ }^{12} \mathrm{~A}$ challenging subject in its own right, it makes the poet a reflexive 'tu' to his own 'toi', a counter-self to be questioned and deconstructed ( $t u$ may also be read as the substantivized past participle of taire, implying that the dark reflection reveals the self's non-dit). ${ }^{13}$ This encounter, in which identity flows from one vessel of the visual hourglass to the other and is then reflected back non-identically, is therefore dialectical in nature, like the contre-corps. Here, too, it is associated with writing, the poet's activity before getting up from his table to close the window, his hand looking like a mouth which appears to eat up the paper as it advances, until it puts down the pen ('la bouche s'efface'). ${ }^{14}$

The second poem explores this virtual external image as a bounded, temporary space of inversion, in which the lineaments of luminous reality inside the room are translated into the shadowy 'fumée' of a nocturnal reflection:

$$
\begin{aligned}
& \text { voici la tente de fumée } \\
& \text { une maison d'envers } \\
& \text { où l'ombre mange l'être } \\
& \text { tu mets tes yeux } \\
& \text { dans la bouche muette } \\
& \text { un geste part en buée } \\
& \text { le mouvement des lèvres } \\
& \text { qui se souvient de soi } \\
& \text { fait un trou d'air } \\
& \text { (EC, p. 220) }
\end{aligned}
$$

The strikingly compressed formulation 'maison d'envers' (we hear 'en verre',

${ }^{11}$ Compare: 'C'est cette nuit qu'on aperçoit si l'on regarde un homme dans les yeux: on plonge alors ses regards en une nuit qui devient terrible; c'est la nuit du monde qui se présente alors à nous. | Je regarde la nuit qui fait de ma fenêtre une pupille énorme et terrible, et je jette le livre dans ce trou' (Le 19 octobre 1977, p. 22).

${ }^{12}$ See my Introduction to La Chute des temps/Timefall, pp. 8-10.

13 'J'ai une grande affection pour le pronom "tu"... le passage vers l'altérité... le passage vers l'autre', in En présence.... entretien avec Bernard Noël, conduit par Jean-Luc Bayard [henceforth En présence...] (Coaraze: L'Amourier, 2008), p. 19. Compare: 'qu'est-ce que la parole || la mort du tu le voyage | où l'on ne va pas' (EC, p. 263).

14 Compare, from Le 19 octobre 1977: 'Maintenant, je regarde ma main. Elle couvre en partie les cinq dernières lignes d'une page qui en compte vingt-quatre. Le pouce et l'index forment une bouche dans laquelle est fiché un stylo' (pp. 17-18). In Le Roman d'un être, watching Opalka's hand as it paints his indefinite sequence of numbers, Noël remarks that 'le mouvement est celui de l'écriture' (p. 13), and repeatedly describes it as the mouth of a small animal: 'la pointe du pouce bouge petit museau grignotant' (pp. 13-14); 'le pouce dont le bout a des mouvements de bouche mâchant' (p. 39); 'la main dans son mouvement sur place semble becqueter' (p. 88); 'la main qui grignote l'espace' (p. 120); 'la main touche grignote avance' (pp. 123-4); 'la main au travail [. . .] petite bête nue qui rumine ou grignote' (p. 132). 
but also perhaps remember the 'maison de verre' from André Breton's protestation, in the opening pages of Nadja, that his text is a transparent representation of selfhood) ${ }^{15}$ lexicalizes this spatial sablier as a place of inversions and exchanges. ${ }^{16}$ The virtual space continues to be characterized by its intangibility, speech is reduced to a 'buée' (the mist of breath on cold glass, though 'part en fumée' might have been expected), and the illusion of depth expressed as a figural double negative, the 'trou d'air' (literally, a hole in something already invisible $)^{17}$ of mental space and memory. Intriguing too is the renewed theme of eating: just as the writing hand ate up the paper in the first poem, so here the virtual 'ombre' of the poet's reflection seems to eat up (or into) his essential self or 'être'. ${ }^{18}$ When combined with the theme of memory in line 8 , in partial response to the opening question 'qu'est-ce que le temps', this makes the reflection a temporal as well as a spatial figure and suggests that we are once more in the domain of writing: ombre, fumée, and buée share the immaterial nature of verbal meaning, the 'maison d'envers' and the 'trou d'air' may also be read as referring to the virtual space of the text, and the disruptive vision of an eroded self is transferred directly to the speechless mouth of the reflection, the 'bouche muette' that is also the poet's writing hand. Thus the figural instrument of the dark mirror sets up a compressed but fertile analogy between world, mind, and page through which meanings will be filtered, permuted, and exchanged to create the 'maison d'envers' of the poem cycle.

The poet's experience of his mirror-self, thematized in the fourth poem of sequence 4 , is clearly a troubling one which he does not welcome but cannot avoid:

qu'est-ce que le miroir

l'eau de l'œil resté dans le verre

le vif du jour collé au mur

la pensée descend vers le fond

sans faire la moindre ride

15 'Pour moi, je continuerai à habiter ma maison de verre, où l'on peut voir à toute heure qui vient me rendre visite, où tout ce qui est suspendu aux plafonds et aux murs tient comme par enchantement, où je repose la nuit sur un lit de verre aux draps de verre, où qui je suis apparaîtra tôt ou tard gravé au diamant' (André Breton, Euvres complètes, ed. by Marguerite Bonnet and others, 3 vols (Paris: Gallimard, 1988-99), I (1988), 651, emphasis original).

16 These also concern memory and the poet's past: 'une maison d'histoire / une maison de temps' (EC, p. 222).

17 Also, perhaps, the sudden plunge of an aircraft encountering an air pocket.

18 Eating and digestion elsewhere characterize how vision internalizes reality before transposing it into expression: 'l'œil saisit tout cela et le prend | puis l'ayant mangé dans son élan | voici qu'il en fait de l'image | ou du verbe étrange digestion | qui transpose et ne digère rien | transpose divinement les choses | en leur donnant une chair d'illusion' ('Fable de l'œil', in Bernard Noël, Un livre de fables [henceforth LF] ([Saint-Clément-de-Rivière]: Fata Morgana, 20o8), pp. 91-98 (pp. 95-96)). 
si seulement ne venait pas de face

le moi qui là-bas s'enfonce

à chacun sa ration d'ombre

pour s'habiller d'image

(EC, p. 250)

Here, images of life, light ('le vif du jour'), and transparency (the glass in which the gaze sees its own 'eau de l'œil', or the limpid pool of vision into which it slips, like a swimmer) are suddenly undermined by dark shadows and anxiety about the self-image ('si seulement') which appears in the mirror's depths. Though he seeks to dismiss these negative portents in a pseudo-saying ('à chacun sa ration...'), it is clear that the 'ombre' of the title is more than just an image: it is a threateningly intimate presence with which the poet has to come to terms, at once intangible and spectral (the semantic extension of ombre in French covers both 'shadow' and 'shade', an archaic synonym of 'ghost', an ambiguity on which Noël plays). ${ }^{19}$ This disturbing Other materializes pictorially in an approximately contemporary series of ink washes called 'têtes d'ombre' which Bernard Noël produced in the late 1980s, publishing a sample of them in a book of the same title. ${ }^{20}$ In his short preface, Alin Avila presents Noël's technique of lavis as an inverse of writing, its sablier counterpart in which the poet's striving for meaning is relinquished in favour of accidental revelation:

Le lavis conduit à la dérive les instruments de l'écriture: l'auteur n'est plus celui qui porte le sens, il n'instyle pas et ne décide de rien. Dès qu'il pose sa plume à fleur de papier, l'eau qui le recouvre finement pompe l'encre et la dirige selon les règles de son cours. (n.p.)

Since we are powerfully programmed to recognize faces, however, the viewer identifies the resultant forms as blurred and ghostly human faces, and the lavis becomes a dark mirror, a (photographic) negative to the verbal imagery of Noël's poetry, a death's head which captures by inversion the temporal origin of selfhood:

Regard qui porte projet en tout, voilà des vis-à-vis. Miroirs sombres où surgissent des têtes d'ombre. Envers des mots lumineux que taille habituellement Bernard Noël. Négatif ou matrice de l'être: l'eau sous l'instant remonte à la probable origine. (n.p.)

19 Le Petit Robert (1993) gives as one definition: 'Apparence d'une personne qui survit après sa mort', and lists as synonyms: 'âme', 'double', 'fantôme', 'mânes' (s.v. ombre, II, 5). Other figurative uses imply concealment ('mettre quelque chose à l'ombre'), secrecy ('vivre dans l'ombre'), mystery ('zone d'ombre'), unreality ('théâtre d'ombres'), impermanence ('passer comme une ombre'), and loss ('être l'ombre de soi-même'). 'Avoir peur de son ombre' (to be excessively timid), and the archaic 'être comme l'ombre et le corps' (to be close friends), are perhaps also peripherally relevant.

${ }_{20}$ Bernard Noël, Têtes d'ombre, preface by Alin Avila (Paris: Area, 1988). Other examples are reproduced in Régine Detambel, Bernard Noël, poète épithélial (Paris: Jean-Michel Place, 2007), pp. 55,81 , and 102 . 
Finally, suggests Avila, as we start to read emotions into these 'têtes d'ombre' ('Espoir, angoisse [...] sourire ou rictus'), they come alive for us, speak to our memory, and, after an aleatory detour through abstract plasticity, meaning comes back into its own: 'La machine du sens, ailleurs, a retrouvé son sens' (n.p.).

A key text for understanding Noël's mirror experience, its connection with time and the visual-poetic tête d'ombre which it reveals to the poet, is a remarkable short essay of a quarter of a century before 'L'Ombre du double' on the Surrealist artist Hans Bellmer. Its title, 'L'Autre corps', alludes to Noël's earlier preoccupation with the contre-corps, as well as to Bellmer's most famous creation, 'La Poupée'. ${ }^{21}$ The opening paragraph describes the poet's confrontation with that supposed agent of visual mimesis, the specular sablier, in terms of a startling and alienating difference of self, recognizable but negatively transformed:

Vous êtes devant le miroir. Vous ne voyez que votre visage. C'est l'habitude. Mais le miroir, qui le voit? Qui y pense? Vous vous dites: je vais regarder le miroir - regarder sa surface et non pas mon reflet. Les yeux, très vite, font mal, ou les tempes, ou le creux des orbites. Vous insistez quand même. Alors monte un drôle de brouillard, qui rend toute chose indécise, tremblée, diffuse. Sans doute, vous abandonnez là, mais vous restez à la question. Aussi, un jour ou l'autre, vous recommencez l'expérience. Vous revoyez le brouillard, vous essayez de tenir encore, de voir plus loin. Et soudain, quelque chose vient: une forme, un visage d'après la mort, le vôtre. (13C, p. 41)

For Noël, acknowledging this strangely alienated future self ${ }^{22}$ as it emerges from the fog of the mirror is a gradual process, one we start to recognize as also guiding the thematic development of 'L'Ombre du double':

Et voici à peu près ce qui vous arrive: du brouillard émerge une forme, de la forme émerge quelqu'un, de ce quelqu'un émerge Vous, et de Vous émerge un crâne vide un squelette. (13C, p. 42)

Confronting the death's head in the mirror allows the poet/artist to 'apprendre à lire [sa] mort', as he realizes that the reflection is also temporal and the specular hourglass rediscovers its vocation as a recorder of time: 'Le temps, c'est l'ombre de vous-même qui s'éloigne de vous et devient l'Autre'. ${ }^{23}$

${ }^{21}$ Treize cases $d u$ je (Paris: Flammarion, 1975), pp. 45-50. Subsequent references will be to the more recent edition (Paris: P.O.L., 1998), pp. 41-45 (henceforth ${ }_{13} C$ ). On the link between mirror and contre-corps see my article "et ma logique va en rond"', p. 115. Bellmer published early photographs of his doll under the title 'Poupée, variations sur le montage d'une mineure articulée', in Minotaure, 6 (Winter 1934-35), pp. 30-31.

${ }^{22}$ There is an echo of Wilde's Portrait of Dorian Gray (1890) in this temporal mismatch between the subject and his future image. There are also analogies here with the parapsychological practice of 'scrying', where visions of the future are seen in a crystal ball or reflective media, including darkened mirrors.

${ }_{23}$ Compare the phrase 'l'ombre du temps' from 'Vers le Daiveland' of 1969 (EC, pp. 121-27 (p. 127)). 
To explain this, Noël invents 'une formule [. . .] un peu barbare: Je ne suis pas je, je est l'Autre' (13C, p. 42, emphasis original) with evident Rimbaldian echoes. However, his statement of alienated identity differs in one key respect from his predecessor's famous 'Je est un autre': ${ }^{24}$

Mais, sitôt posée, cette formule implique sa réversibilité, et vous voici tout à coup en possession de la seule clé qui pourrait rendre les choses fixes, remettre des yeux dans les orbites vides ou rendre un corps à votre amour perdu. Et si la réversibilité n'existe pas, ou bien si elle nous échappe, il n'y a qu'à l'IMAGINER. (13C, p. 42, emphasis original)

This wished-for reversibility of identity, an exemplary manifestation of the mirror-sablier's figural invertibility, now in time as well as space, may indeed be impossible to realize, but that aspiration nevertheless becomes the primary driver of expression: 'Qu'est-ce qui nous fait écrire des traits ou bien tracer des mots, sinon la nécessité de cette imagination-là?' $\left({ }_{3} C\right.$, p. 42$)$. The 'Autre', 'double', or contre-corps that the poet or the artist may construct in their work is an attempt to reverse the flow of time towards death, to put flesh back on the skull of the 'tête d'ombre' and create an alter ego that will outlive them:

écrire, c'est diffuser notre physiologie. Mais chaque geste est une écriture, et peut-être, à force d'en remplir invisiblement l'espace, y créons-nous une sorte d'anatomie inconsciente: un autre corps, dont pages et dessins ne sont, à leur tour, qu'un reflet, une trace. (13C, p. 43)

Noël's conclusion here, which applies no less to his own poetry than to Bellmer's art, returns to the figure of the autre corps articulated in his earlier works, now as a gestural 'anatomie inconsciente' mediated by the reflexivity of the mirror and re-reflected, in turn, by the poem or the picture.

The specular encounter with a shadowy alter ego narrated and enacted in 'L'Ombre du double' ('qu'est-ce que le face à face | du fond de la vitre vient | le tu qui n'est pas de l'autre' (EC, p. 229)) possesses the same figural characteristics as other sabliers constructed by Bernard Noël. Two parallel, equal, and permutable domains reflect and (re)double each other:

le regard voit son double et bute contre lui-même

(EC, p. 249)

\footnotetext{
24 'Lettre du voyant' (letter to Georges Izambard, Charleville, 13 May 1871), in Arthur Rimbaud, Euvres, ed. by Suzanne Bernard and André Guyaux (Paris: Garnier, 1987), p. 347. A century later, in the essay 'La Rencontre au milieu du pont' (on Gustave Meyrink), Noël ascribes this alienation to an active property of the mirror: 'les miroirs sont des signes, et si polis que chacun peut les lire à sa guise puisqu'ils ne font que nous retourner notre image; mais que se passerait-il s'ils avaient un sens? Peut-être celui qui s'avance vers nous à mesure que nous avançons vers lui cesserait-il alors d'être un Je familier pour devenir soudain un Autre ou bien le double' (13C, pp. 46-50 (p. 49)).
} 
At the same time, this relationship invites visual, semantic, and existential inversions which generate a rich thematics of identity-as a key assertion from the second canto of La Chute des temps (1983) implies:

mais les hommes ne sont

que l'envers de leur ombre

$(C T, \text { pp. 45-46) })^{25}$

Together, therefore, the two poles of the title 'L'Ombre du double' embody and exemplify the macro-strategy of Noël's enterprise to construct a textual 'maison d'envers', or paradoxical mirror of selfhood. That this was not a new initiative but one with a long gestation is indicated by the fact that their pairing in the 1993 title was directly anticipated a quarter of a century earlier in another poem about relational identity, 'Le Jeu du tu nous je' of $1968 .{ }^{26}$ Here, in imagery familiar from Noël's earliest work, the $j e$ falls vertiginously through a constricting sablier before experiencing the alienation of his double, expressed in the 'squared' logic of the shadow/shade's shadow:

\author{
avec ce cri dedans \\ cri de quelqu'un qui tombe en soi \\ cri du fond d'un puits ${ }^{27}$ \\ vous avez vu mon double \\ je m'en allais de moi \\ j'étais cette fumée \\ comme l'ombre d'une ombre \\ (EC, p. 92)
}

This doubled expression of evanescence, paired with the shifting intangibility of 'fumée', points to a key quality of the poet's mirror experience: its lack of somatic, material foundation, its doubled abstraction.

Like the poetic text, built from mentalized tokens of reality, the mirror dematerializes what it purports to reproduce. This is what gives it the figural flexibility to permute and invert its 'contents', as the third poem from 'L'Ombre du double' suggests:

la vue plie dehors sur dedans

île de nuage et de bulle

à l'intérieur ce pli de rien

25 Compare: 'Un homme n'est entier que s'il tient compte de son ombre aussi bien que de lui-même' (Le 19 octobre 1977, p. 42).

${ }^{26}$ In Bernard Noël, La Peau et les mots (Paris: Flammarion, 1972), pp. 113-26; also Poèmes 1 (Paris: Flammarion, 1983), pp. 173-84, and EC, pp. 87-98.

27 Compare: 'Et cela découpe un puits. Le sexe y remonte. Les yeux y tombent. Un puits en moi, fait de moi, contre moi' (EC, p. 42). 
le toi s'y replie sur l'autre

même toi que toi tout en rien

$$
(E C, \text { p. } 221)^{28}
$$

Here, the 'folding inwards' of external reality into mental space is conveyed by intangible phenomena ('nuage', 'bulle', 'rien'), the isolated 'île' and its thirdperson homonym being a figure of both mirror and mind in which the 'toi' of the poet's image, reflected into his own self-aware gaze, becomes subject to the same dematerialization as other aspects of the visible world ('rien'), while remaining itself ('tout'). This combines, as a poem from sequence 3 indicates, with a sense of distancing, both visual and psychological, to alienate the self from its specular image: 'le corps soudain manque de corps | il continue si loin de lui-même' (EC, p. 242). ${ }^{29}$ The link between dematerialization and alienation is analysed in the later text 'Fable de l'œil' ( $L F$, pp. 91-98) as a property of the gaze itself: the physical eyeball has a dark 'puits' at its centre from which emanates a mental 'souffle noir', negative inversion of the luminous air of external reality and force of negation of substance:

mais de quelle nature sont ces globes chair pleine et chair trouée avec dans leur milieu ce comble du mystère un puits où le Néant affleure peut-être est-ce de là que monte le souffle noir qui met du rien dans la substance des figures celles du souvenir ou des poèmes parfois les yeux plantés dans le miroir l'un fixant l'autre puis l'autre l'un on cherche le secret de l'acide qui dissout le visible et fait sous lui fleurir l'absence et la chose abolie mais la vision gratte soudain le verre quelques larmes brouillent la profondeur tout se décharne [...]

$$
(L F, \text { p. } 96)^{30}
$$

Here, the pupil's brimming 'Néant', a double-negative, fluid 'rien', affects

${ }^{28}$ Journal du regard has the same visual sablier: 'L'œil contient le vu et contient le regard. L'œil réfléchit l'image et il en est la réflexion. Je pense en moi, mais également hors de moi, dans un mouvement perpétuel du dedans et du dehors, du projeté et du réfléchi dont le croisement produit cet objet mental: l'image' (pp. 17-18).

29 In a later text in the cycle this 'manque' extends to the confiscation of the poet's body image: 'mais l'autre là-bas dans la fumée | porte le corps qui fut mien' (EC, p. 264).

${ }^{30}$ Compare the quotation from 'Le Jeu du tu nous je', above. For the metaphor of the pupil as a well-shaft, configured as a sablier between external and mental spaces, see Noël's essay on Julien Gracq from the early 1970s, 'L'Avènement du nom': 'Reste cependant, à l'intérieur même de l'œil, un rond de ténèbres; oui, ce moyeu de nuit autour duquel on voit. Pupille, le puits noir, tour d'ombre renversée vers quelque ciel de tête' (13C, pp. 21-26 (p. 21)). 
not just the specular image of self (expressed in the quasi-palindromic 'l'un fixant l'autre puis l'autre l'un'), but all the mental images we use to convey our experience ('[l]es figures $\mid$ du souvenir et des poèmes'), confirming the interrelationship of mirror, mind, and page in Bernard Noël's textual world. ${ }^{31}$ Fundamental to this triple equivalence is, again, a process of visual inversion, as the 'souffle noir' of the mentalized gaze becomes the acid used by an engraver to etch a negative, inverted image onto the plate. ${ }^{32}$ The result is a Mallarméan flowering of absence, experienced initially as positive but then leading to disappointment as the poet becomes aware of the artifice of illusion ('la vision gratte soudain le verre', like a fingernail) and the loss of materiality ('tout se décharne').

\section{Writing the 'double'}

The function of the mirror-sablier in Bernard Noël's poetry is thus by no means limited to the visual domain. The illusory depth that the reflection opens up is a direct analogue of the poet's mental space, where he can inspect and engage his own thought, in dialogue with 'celui qui a mon regard | dans la vitre noire' (EC, p. 263):

$$
\begin{aligned}
& \text { à moins que tout cela } \\
& \text { un creux dans la tête } \\
& \text { une pensée debout } \\
& \text { devant son ombre } \\
& (E C, \text { p. 224) }
\end{aligned}
$$

As the poet continues to explore his 'maison d'envers' in 'L'Ombre du double', the figure of the dark mirror generates a rich lexicon of variations on the themes of self and other, past and present, light and dark, seeing and writing, of which the present article has scope only to give a flavour. As early as the fourth poem of sequence 1 , the reflected $t u$ is identified, in answer to the question 'qu'est-ce que le mystère' (EC, p. 222), as his 'double':

${ }^{31}$ Compare: 'la page de verre monte | le visage éclate dedans' (EC, p. 234); 'un tu taillé dans le regard | il creuse en face le même trou | central que dans l'œil' (EC, p. 245).

${ }^{32}$ Elsewhere, the 'souffle noir' of mental activity is likened to the development of a photographic negative in the darkroom of the mind: 'Nous avons deux regards, l'un qui se répand au dehors, où il crée le visible et son volume; l'autre qui se répand à l'intérieur, soit pour y développer le visible, soit pour y voir qu'il ne voit rien que la coulée bruissante de l'air noir. | L'imagination nage dans cet air-là et s'y révèle comme l'image dans la chambre obscure' ('L'Expérience extérieure', preface to the exhibition catalogue Fred Deux, l'expérience extérieure (Paris: Jeanne Bucher, 1983), n.p.). In a 1973 interview with André Miguel, Noël presents the whole inner body as a camera (obscura) or darkroom (chambre noire covers all three related photographic concepts): '- Le regard poétique, c'est sans doute le moment où tout le corps devient chambre noire. Je sais que je n'écris rien qui ne soit passé d'abord par cette chambre, avant de se développer en mots' (13C, pp. 95-98 (p. 97)). 


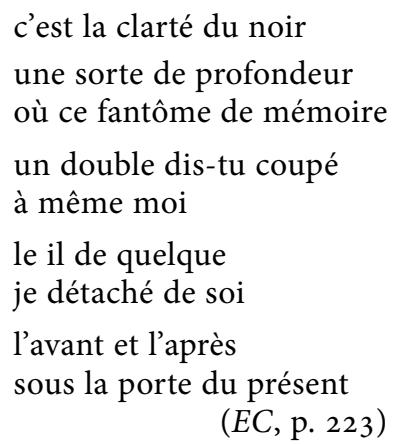

As implied in the opening question of the cycle, the 'il' observed here in the inverted 'clarté du noir' (dark mirror and mind) is intimately bound up with time: 'ce fantôme de mémoire', seen in the present, opens up both the poet's past and his future. This temporal property is stressed in the second response to the question 'qu'est-ce que le miroir', which connects the 'unité [. . .] fumeuse' of the mirror image with (past) memory and (future) forgetting, as if 'souvenir' and 'oubli' (like 'l'avant' and 'l'après', above) were the two vessels of a sablier communicating through a present mirror surface: ${ }^{33}$

$$
\begin{aligned}
& \text { quelque chose une forme veuve } \\
& \text { tu te vois en souvenir } \\
& \text { une trace comme un visage } \\
& \text { l'unité enfin mais fumeuse } \\
& \text { à peine un contour } \\
& \text { on enterre ta ressemblance } \\
& \text { dans ton propre regard } \\
& \text { plus de présence exacte d'identité } \\
& \text { le premier état de l'oubli } \\
& \text { (EC, p. 251) }
\end{aligned}
$$

This interment of the mimetic self-image has positive connotations for Noël's rejection of superficial appearances, but leaves the poet 'widowed' of any stable self from which to understand his past life and future disappearance. ${ }^{34}$

It is also significant that, in 'L'Ombre du double', the dark window/mirror is not just a metaphor but a physical mechanism, a pane of glass which mists over when breathed upon:

33 In the first sequence, the mirror also articulates spatial and rhetorical sabliers: 'fumée d'ici et là montant || de part et d'autre | du soi noir || parmi l'aveugle | dialogue du oui non' (EC, p. 226, emphasis added).

34 'puis la noirceur prend | toute la chair du moi || la mort l'habille en tu | dans ma blessure' (EC, p. 231). 
tu souffles dans la vitre

tu sens que ta tête s'embue

(EC, p. 254)

As the visual self-image reflected in the pane blurs, so the corresponding mental space of the je (the parallel sense of 'ta tête') becomes 'misted'-but also, more positively, fills with concepts and words. For buée, in Bernard Noël's figural lexicon, is associated with meaning, particularly its materialization when mental souffle is externalized in speech ('cette buée là-bas | sur la langue un nom' (EC, p. 238)). ${ }^{35}$ While the poet's breath literally mists the mirror reflection, therefore, it also produces a mental-verbal image in his head, a product of the reflexive process:

\section{transparent je et tu \\ sont la sueur du verre}

(EC, p. 230)

Later, the window's surface and specular mechanism are revealed by an 'haleine d'os', the paradoxical 'breath' of the future skull that will continue to 'speak' the dead poet's image from within his writings, further linking the mirror with the 'trou d'air' of the mind:

$$
\begin{aligned}
& \text { un trou d'air une haleine d'os } \\
& \text { celui que tu n'es pas encore } \\
& \text { te fixe avec les yeux que tu as } \\
& \text { l'avenir gonfle la vitre } \\
& \text { la surface est de ton côté } \\
& \text { trop de noir au-delà } \\
& \text { trop de lumière en-deça } \\
& \text { (EC, p. 252) }
\end{aligned}
$$

The air-filled (mental) space 'behind' the dark mirror, carrying intimations of his mortality, stands here in a balanced spatial, temporal, and syntactic sablier relationship with the luminous, present interior. ${ }^{36}$ But crucial for the present poet is that 'la surface est de ton côté, for it is this awareness of the mechanism of self-reflexivity, the misted mirror-glass, that makes us fully alive, and that awareness is lost in death:

qu'est-ce que la mort

l'oubli de la vitre et tu entres dans la matière

(EC, p. 240)

35 See also 'un geste part en buée' (EC, p. 220), above.

${ }^{36}$ Compare this temporal sablier from La Chute des temps: 'tout jaillit au présent | ce qui advient | ce qui toujours s'en va' (CT, p. 144). 
The third line suggests a double reading, that forgetting the mirror means less espousing some 'real' image ('getting down to business'), than literally returning to the physical world ('dust to dust'). It is clearly an anticipated death-mask that is presented in the following poem, in a second answer to the above question:

c'est de la forme et non du moi
visage sans aucun trait
l'épaisseur peut-être du silence

(EC, p. 241)

By the end of the cycle it seems clear that this death's-head 'ombre' has taken control. The closing lines of the final poem suggest the victory of dark over light, past over present, death over life, and a definitive inversion of the specular and rhetorical sablier in which the 'vehicle' (dark image) has overwhelmed the 'tenor' (observing self):

et le tu dévore le je
puis le recouvre de son ombre
les morts enterrent les vivants
dans leur propre peau de ténèbres

(EC, p. 265)

The poet's features in the mirror are here covered over by a visually inverted, negative skin, ${ }^{37}$ a textual ombre/double that not only will outlast his own lived identity, but is already, from the moment of writing, starting to supplant it - for the reader, but also for the author himself as he 'reads' in it his own mortality.

'On écrit le double': this affirmation, concealed in the acrostic of the first poem of the second sequence of Bruits de langues (published in 1980, but written and gradually pre-published over many years previously), ${ }^{38}$ reflects a key principle of Bernard Noël's composition. As he remarks in a short note from the third (1975) part of 'Le Chemin de ronde': 'Écrire, n'est-ce pas vivre son double?'39-a rhetorical question answered almost twenty years later by the narrator of Le Syndrome de Gramsci: 'Oui, l'écriture est comme la vie, mais en lui inventant une doublure. ${ }^{\prime 0}$ In his 2008 interviews with Bayard he

37 Compare: 'la peau de quelque pensée morte' (EC, p. 249), and the title of Noël's first collected volume, La Peau et les mots (Paris: Flammarion, 1972).

${ }^{38}$ Bernard Noël, Bruits de langues (Le Rœulx: Talus d'Approche, 1980); also in EC, pp. 147-99 (p. 162). On the complex system of acrostics governing the collection see Jean-Luc Bayard, 'B.N. rit du rien: une lecture de Bruits de langues', Faire part, 12-13 (1989), 159-64.

$39{ }_{13} \mathrm{C}$, pp. $105^{-27}$ (p. 110). Cited inaccurately in the affirmative by Claude Margat in a recent interview with Noël: see Bernard Noël and Claude Margat, Questions de mots - Entretiens (St-Georges d'Oléron: Éditions Libertaires, 2009), p. 52.

$4^{\circ}$ Bernard Noël, Le Syndrome de Gramsci (Paris: P.O.L., 1994), p. 61. 
extends this to all artistic expression, each medium a mirror reflecting the double's image:

Pour s'exprimer, il faut avoir face à soi une sorte de double 'virtuel' sous la forme d'une feuille de papier, d'une toile, d'un écran... choses sur lesquelles la vie intérieure vient se déposer et laisser son empreinte.... Et le surprenant dans ce processus, c'est que s'exprimer consiste au fond à s'intérioriser à l'extérieur... (En présence..., p. 39)

The poet's shadow-double is thus simultaneously a private alter ego, a public textual construct, and an imaginary extra-textual interlocutor that dialogically includes the virtual reader. This multifaceted other, carried by the text in its many reflexive figures, is not readily analysable into its different aspects because they interrelate in a mutual exchange of characteristics, which perhaps accounts for an anxiety expressed in the opening words of the tenth poem in the first sequence of Bruits de langues:

et comment

trancher le double

(EC, p. 162)

The textual ombre/double and the 'real' self of the writing je are indeed bound to each other like conjoined twins, exchanging characteristics, with variation, doubling, and inversion, between the dual vessels of the mirror-sablier to construct a hybrid identity. This complex interaction is captured in the third poem in response to the question that opens sequence 3, 'qu'est-ce qui nous fait vivant' ( $E C$, p. 237), which establishes a persona that is simultaneously 'il', 'vous', 'qui', 'moi', 'personne', 'quelqu'un', and 'je':

il et vous et qui poussière

du corps étoffe de moi

sur personne un peu de noir

quelqu'un est sortie du souffle

il a mangé mon visage

il est où je suis

quand je ne suis rien

un sac de ténèbres

sens dessus dessous

(EC, p. 239)

This complex multiple identity, which covers the null presence in the text in an 'étoffe' of bodily dust (we remember the granular matter precipitating through the sablier of Extraits du corps), emerges from the poet's mental space as a verbal 'souffle' which undermines his 'real' image and usurps his place in the poem-where, however, he can have no physical presence, and not just after death ('quand je ne suis rien'). The poet dismisses this textual 'ombre' as 
a mere 'sac de ténèbres', yet the final line, which repeats verbatim one from the first contre-chant of La Chute des temps (CT, p. 36), also reaffirms the productive vitality of the inversion strategies on which Noël's compositional method relies: being alive does emphasize the negativity of written selfhood, but also allows exploration of its rich semantic connections and figural possibilities. ${ }^{41}$

There is, for Bernard Noël, an important ethical dimension to the writing of poetry, which requires a principled, arduous, and tenacious inversion of accepted values and expectations. In answer to the question posed in the opening poem of sequence 4, 'qu'est-ce que la volonté, Noël presents the poet's lot in a sequence of images of discomfort, compulsion, and suspicion of mimesis, but also a constant awareness of ageing and death:
L'ongle grattant les images ${ }^{42}$
le coup de poing dans le reflet
le choix de n'avoir plus le choix un peu de vieillesse jetée sur l'enfant un doigt derrière les yeux la langue nouée à l'objet

(EC, p. 247)

The last of these, the poet's tongue/language tied to/knotted in battle against concrete phenomena, gives a sense that writing is a constant struggle to make expression adequate to reality, when language, the only material available, is so abstract, intangible, and separated:

la bouche lutte avec une matière de vent un goût de fêlure

(EC, p. 242)

In the third 'Chemin de ronde' this intangibility is described using the most negative, deathly associations of the 'ombre' metaphor:

Les mots projettent en avant une ombre que l'on pourrait prendre pour la vie, alors qu'ils ne sont eux-mêmes que l'ombre morte de la vie. (13C, p. 110)

As Noël makes clear in 'A Bruno', a 'Lettre verticale' addressed in 1975 to Bruno Roy, owner of publishing house Fata Morgana, and his wife Marijo, trying to construct a viable image of self in language is inevitably unsatisfactory:

${ }^{41}$ Béatrice Bonhomme remarks on 'Le moi profond où réside sans cesse le vide du vide, mouvement vers le vide qui finirait par s'inverser, le poème constituant une faille et un pont tout à la fois' ('Huit Variations sur l'œuvre de Bernard Noël', in Avec Bernard Noël toute rencontre est l'énigme, pp. 35-47 (p. 40)).

${ }^{42}$ Compare: 'mais la vision gratte soudain le verre', discussed above. 
je mâche de l'ombre

en parlant de moi. ${ }^{43}$

Yet the poet cannot escape from a commitment to words, however fleeting and inadequate the 'ombre' of self, and reality more generally, they generate in the textual mirror.

The second 'Chemin de ronde' (dated 'juin 1965-1968') presents writing as a matter of waiting in stillness to lure the mental image into a strange negative copulation which may produce, almost as a by-product, some fragment of poetry:

D'abord, une espèce d'obstination dans la passivité: je me contrains à être la proie de l'ombre. Je l'appâte à force d'immobilité, de non-défense, d'espace découvert. Étrange jeu d'amour avec rien - avec un rien qui va me faire quelques mots. Et qui n'aura jamais d'autre présence que ces déchets de notre amour. ${ }^{44}$

In a double inversion of La Fontaine's 'Le Chien qui lâche sa proie pour l'ombre' and the saying derived from it, the poet here deliberately offers himself as bait to a mental rien which he tries to tempt into expression, while knowing that he cannot capture any presence more substantive than a verbal shadow/shade. ${ }^{45}$ From 'L'Autre corps', the essay on Bellmer discussed above, we gain a sense of what the momentary success of such a verbally captured encounter with the mirror image might feel like, Noël again describing an erotic experience in which space (behind and in front of the mirror) and time (before and after) are fused in a moment of plenitude:

Mais rappelez-vous d'abord le miroir, et comment votre corps successivement s'y dédouble et s'y retrouve. Rappelez-vous la peur puis l'étrange plaisir quand l'envol et l'effacement de l'AUTRE CORPS vers le fond rendent tout à coup le temps visible comme une ombre - comme le déplacement d'une ombre. Si vous réussissez à fixer ce déplacement, vous entrez dans l'instant, qui est cette image où l'avant et l'après sont là en même temps. Et la tension de tout cela, à l'intérieur de l'instant, fait que l'espace, dirait-on, y est gonflé: qu'il s'érotise tout entier. (13C, p. 43, emphasis original)

However, as is suggested in the opening of the contemporary essay on Julien Gracq, 'L'Avènement du nom', this reflexive luring quickly ends in disappointment. Here, the word 'ombre' is initially raised, as it were, to the power of itself, a complex sablier structure in which a literal shadow, the intangible

$4313 C$, pp. 167-74 (p. 173). Noël's 'Lettres verticales', epistolary poems to intimate friends written through much of his career, are characterized by their acrostic 'spine'. Here, the first word in the line, 'je', is redoubled (squared) because it can also be read vertically.

44 Bernard Noël, 'Le Chemin de ronde II', in Le Lieu des signes [henceforth LS] (Paris: Lignes et Manifestes, 2006), pp. 101-35 (p. 131).

45 On this moment of mental disponibilité which precedes writing, see my discussion of 'encore', the preface to the second (1993) edition of Noël's La Chute des temps, in La Chute des temps/Timefall, pp. 21-23, and my article "'et ma logique va en rond", pp. 120-21. 
secondary representation of something concrete, in turn casts an abstract, third-degree mental/verbal shadow:

Le mot ombre est-il l'ombre portée de l'ombre?46 A le répéter ainsi triplement, voici au moins un bruit de houle dans ma gorge. Et tout à coup, là-bas, le noir se fend, et quelqu'un - quelque chose happe l'hameçon du présent, encore et encore. Il y a balancement entre le leurre de l'image et le fait d'en être le fabricant, mais la conscience se retourne, puis vainement s'agite: elle est prise aux mots. Alors, reflet sur reflet, ce remuement inlassable, et soudain plus rien qu'une bouche vide et cette page. L'ombre rentre dans le mot ombre, et c'est à désespérer de revoir l'épaisseur à la fois liquide et charbonneuse, où tout à l'heure on se péchait soi-même en jouant de la vague et du temps. (13C, pp. 21-26 (p. 21))

The metaphor this time is of fishing, but again the wriggling self-image ('reflet sur reflet') that the poet has briefly captured by ruse slips off the hook, the vivifying figural interplay ('balancement') between the vessels of the sablier ceases, expressing mouth (writing hand) and page become separated again, and the sensual 'épaisseur à la fois liquide et charbonneuse' of the visible shadow collapses into the tertiary 'ombre' of words. This recurrent dilemma is eloquently presented in 'L'Ombre du double' in the single poem that responds to the final question of sequence 2, 'qu'est-ce que la vie', where the writer's mental hand, with the abstract 'dirt' of the alphabet under its nails, merely creates yet more abstraction as it labours to inscribe the word 'corps':

tu tends ta main de poussière trop de lettres sous les ongles

encore un peu de rien

dans le mot corps

(EC, p. 235)

For all his efforts, the poet's textual presence can never be more tangible than this disappointing 'poussière | du corps' (EC, p. 239, quoted above).

Yet, in a move going back to the earliest days of 'Contre-mort' and Extraits $d u$ corps,${ }^{47}$ it is precisely to the body that the poet continues to look in his desire to ground language in lived experience. In Les Etats $d u$ corps of 1986, its eleven short prose texts accompanied by finely detailed 'anatomical' drawings by Cécile Reims, Bernard Noël restates the general principle that language resides in, and renews itself through exchange with, the body: 'Le corps est une carrière à mots, et ses explorateurs assurent que, là, sous la peau, il y a de quoi refaire la langue. ${ }^{38}$ In a 1994 interview with Domique Sampiero

${ }^{46}$ Compare, from Extraits du corps: 'C'est l'ombre de l'ombre, qui est l'envers effilé de ce qui fait ombre' (EC, p. 42).

$47 E C$, pp. 7-14. See also my article '“et ma logique va en rond"', pp. 122-23.

48 Bernard Noël and Cécile Reims, Les États du corps (Amiens: le Nyctalope, 1986); republished by Fata Morgana (1999) and also in EC, pp. 201-13 (p. 212). 
published in L'Espace du poème, he presents this relationship in terms of a sablier structure, a physical body linked to a cultural 'double' by a hinge or central pivot:

Peut-être que le centre du corps serait le lieu où la langue..., comment dire... où ça prend langue. Parce que nous avons deux corps, un corps physique sur lequel est greffé un corps... disons... culturel. Le centre serait peut-être le lieu de la greffe, la ligne sur laquelle naissent les mots, ligne à la fois de chair et de fluidité. Ce serait un centre qui bougerait comme une phrase. Un centre ondulé et onduleux. ${ }^{49}$

Philippe Païni also sees this sablier image of the body, simultaneously pivot and hinge, as forming the junction in Noël's poetics between external reality and the space of the poem:

Le regard détermine un espace réel, identique à 'l'espace du poème' parce qu'entre les deux le corps est un pivot qui articule le langage et le réel. A la charnière, le corps de langage a son espace réel..$^{\circ}$

Bringing about the transfer between the two domains is, however, of necessity a laborious process (hence the image of quarrying the body, above), and one which, in 'L'Ombre du double', Noël presents as implicitly a translation (in the etymological sense of 'movement between'), one word at a time:

plus tard le même mot à mot

toujours tissant

son espace de tête

(EC, p. 227)

This translation-transition-transfiguration of lived experience through the physical processes of the body generates, first, the mental space we inhabit, then the poem that we read.

In an essay from 1972 about his own writing practice, 'Changer la mort' (13C, pp. 14-18), Noël reflects on this process, again observing his hand as it writes about itself writing, in a condensed, sablier-like summary of the relationship between language and the body:

49 Bernard Noël, L'Espace du poème: entretiens avec Dominique Sampiero (Paris: P.O.L., 1998), p. 27. When Bayard asks him to explain 'la vraie lumière', Noël returns in quasi-mystical terms to the position on the mind-body problem articulated in 'Contre-mort' (1954): 'C'est une qualité de l'espace... le point où l'espace entre en fusion avec nous-même et s'allège en nous allégeant... Autre chose: toute ma vie j'ai désiré voir comment le corps transpire de la pensée, et cette transpiration est la lumière même, la lumière du corps transfiguré... la posture de l'écriture est l'exercice apte à provoquer cette transfiguration - et peu importe si c'est désespérément!' (En Présence..., p. 67).

50 'Le Corps écrit', p. 73. In his own essay in the same collection, 'L'Horreur et l'extase', Jacques Ancet also employs a hinge and pivot metaphor: 'La difficulté d'écrire sur le travail de Bernard Noël vient de l'impossible même auquel il ne cesse de se heurter: comment accéder à cette charnière, à ce point-basculement où la présence (du corps, de la matière) devient langage (du verbal, du mental)?' (in Avec Bernard Noël toute rencontre est l'énigme, pp. 29-34 (p. 31)). 
Le corps, dis-je. Et il y a devant moi cette main qui écrit. Je la regarde. Elle s'arrête. Elle écrit qu'elle s'arrête, et donc ne s'arrête pas... Cela pourrait servir de prétexte à une observation de l'observation, et j'apprendrais à noter le décalage entre le regard et l'écrit, ou peut-être le trajet de l'image entre sa réalité, sa conscience et son écriture le trajet à travers mon corps. (13C, p. 15)

Writing is here broken down into three stages (experience-its mental perception-its verbal expression) which correspond to a process of corporeal filtering, so that the physical self becomes literally a mechanism for the production of language:

Question alors: Qu'est-ce que mon corps à cet instant? Une machine à penser la réalité et à la nommer. Et si ce corps, en effet, était ce transformateur qui, matériellement, change la réalité en mots? (13C, p. 15)

This notion of the body as a transformer of reality corresponds to an earlier alchemical image from the second 'Chemin de ronde':

Mon corps attendant qu'éclate l'instant de l'écriture est à l'image du fourneau de l'alchimiste: il va transmuer le vide intérieur en la parole. (LS, p. 115)

Whereas in the earliest texts, however, Noël had aimed to generate a contrecorps by verbal mimesis of bodily experience, 'Changer la mort' recognizes the cultural component of expression highlighted in the Sampiero interview, which also explains the abstractness of words, divorced from their physical referents:

Qui parle? Ma bouche. Qui parle par ma bouche? Mon corps. Mais si mon corps a besoin de parler, de se parler, pourquoi la parole a-t-elle perdu à peu près toute évidence physique? Pourquoi la nomination est-elle, par excellence, l'opération abstraite? C'est que le corps ne produit pas son langage: il apprend à parler. On lui apprend. Aussitôt le voici doté d'une espèce de sens supplémentaire, dont les cinq autres ne sont plus guère que les serviteurs ou les pourvoyeurs: le langage. Un sens? Non, le mot n'est pas assez fort: un DOUBLE. (13C, p. 15, emphasis original)

Here, language is not just a sixth, uniquely human sense (in the double meaning of 'sens'), it becomes the poet's Doppelgänger, a body double which, in a later passage, Noël presents ambivalently as parasitic on his own physical existence, much as in 'L'Ombre du double':

Mais la pensée? La pensée est l'instinct génésique du langage. Dès que l'homme balbutie, il met en marche cet élan, qui va féconder ses premiers mots pour en faire naître une multitude d'autres. Tous les prétextes sont bons: la communication, l'amour, le savoir, l'écriture... Et le corps, parasité par les mots, en arrive à oublier qu'il les reproduit: il est doublé. (13C, p. 16, emphasis original)

What marks out the writer from the ordinary user of language, however, is that he is aware of his linguistic parasites, which in fact, as Noël explains in 
another Rimbaldian allusion in the third 'Chemin de ronde', take over his existence and become his primary mode of activity:

L'écrivain s'oublie pour agir dans son double. Agir en l'Autre et non plus en Je. (13C, p. 114)

Perhaps the most radical example of this verbally doubled existence is offered, for Noël, by Joë Bousquet (1897-1950), the paralysed poet of Carcassonne, wounded in 1918 and bedridden for the rest of his life. Rather than alluding to Bousquet's physical incapacity in the set phrase 'cloué au lit', the title of Noël's 1974 article for La Quinzaine littéraire (no. 184), 'Cloué aux mots', stresses his utter dependence on language, which for Noël stands in symmetrical and reversible relation with the poet's mental space, pivoting around the 'point' of his immobilized body:

Le corps immobilisé n'explore plus d'autre espace que lui-même: il est un point, et décide donc de ce qui finit et de ce qui commence. Dans cette mesure, il est le lieu du renversement, le lieu de la réversibilité, car le seul mouvement qu'il produit encore est celui de la pensée, lequel dans ses retours sur soi semble monter et descendre le temps. Écrire et vivre deviennent symétriques... (13C, pp. 197-200 (p. 198))

Noël here presents Bousquet's mental life as a self-reflexive, reversible sablier in which thought flows back and forth between twin vessels of bodily and mental space, and past and future time, to the point where the poet and his writing become like conjoined twins: 'Sa blessure, qui est définitive, l'a définitivement cloué à son double'-a double which is at the same time his specular-textual 'ombre', 'le reflet qu'il fait se lever de son propre corps' ${ }_{13} C$, p. 198).

The apparent equivalence, in Bernard Noël's figural economy, of the terms 'ombre' and 'double' is stated explicitly in another short essay from the early 1970s, 'Le Volcan, la plume', about Malcolm Lowry's 1947 novel Under the Volcano:

Et qu'est alors un livre? Ce jeu, peut-être, où la superposition n'engendre pas une image, mais une ombre. Et cette ombre, pourquoi ne serait-elle pas, bien qu'illusoire, le double appelé par le besoin que nous avons de connaître notre identité? ${ }_{1}{ }_{3} C$, pp. 225-37 (p. 232), emphasis added) $)^{51}$

Both terms refer, therefore, to a textual self/Other that the author creates in the search for self-knowledge, but which is, as he is forced to admit, ultimately illusory because words always 'digest' real phenomena 'en leur donnant une chair d'illusion' ( $L F$, pp. 91-98 (pp. 95-96)). ${ }^{52}$ In his 2008 interview with

${ }^{51}$ Compare, in a 2009 interview: 'si l'expression est le double que je laisse à l'extérieur de moi' (Bernard Noël and Claude Margat, Questions de mots - Entretiens, p. 75).

52 See $n .18$ above. 
Jean-Luc Bayard, he describes trying to resist and reverse this drift during the composition of 'L'Ombre du double', using a paradoxical image of (self-)sacrifice:

Quand j'écrivais L'Ombre du double... Il m'est arrivé cette chose étrange: je me suis vu sacrifier l'illusion avec un couteau d'illusion... L'illusion bien sûr que crée l'exercice de l'écriture. Et ce n'était pas une image alors que cela le devient en le disant... On reproche aujourd'hui à la littérature française d'être auto-réflexive... en ignorant que c'est pour elle le moyen de devenir concrète... (En Présence..., p. 53)

The poet here seeks to 'sacrifice' his illusory double in order to create a more authentic self-image, but faces the impossibly circular challenge that the only weapon available is language itself, as explained in section 16 of 'Le Reste du poème' (1997):

comment fouiller la chair avec ce couteau

la lame est d'illusion et le manche aussi

et le but n'est pas si différent lui-même

l'outil mental cherche en vain le bon tranchant

$(R V, \text { p. } 107)^{53}$

However much the verbal 'couteau d'illusion' is turned against itself, it will never be genuinely able to 'operate' on the body or turn the illusion of a textual Other into a concrete reality. Worse, in the constantly renewed attempt to achieve this through writing, in the end it is not the double that is knifed by language, but the self of the writing $j e,{ }^{54}$ sacrificed to its parasitic demands:

plus tard le même mot à mot

toujours tissant

son espace de tête

toujours levant

le même couteau d'air

le sacrifice du je

au tu

l'égorgement verbal

de l'illusion par l'illusion

$$
(E C, \text { p. } 227)^{55}
$$

53 'La Fable à l'envers' connects the linguistic 'knife' homophonically with dualism and the mind-body problem: 'quelqu'un entre dans son corps | où sont dedans et dehors | il prend un couteau sans lame | pour tenter de trouver l'âme' (LF, pp. 99-107 (p. 105)).

54 A further echo of Dorian Gray's misguided attempt to 'murder' his portrait-self.

55 Compare 'le venteux couteau | qui tranche le verbe dans la gorge', from 'La Fable et le vent' $(R V$, pp. $183-202$ (p. 201)). In the atmosphere of the writers' retreat at the monastery in Saorge, however, Noël detects a more positive 'incitation à mettre dans le quotidien le tranchant et la dureté qu'on ne trouve plus guère que dans la pratique de la syntaxe' ('Préface' to Chantal Dupuy-Dunier, Saorge, dans la cellule du poème ([Montélimar]: Voix d'encre, 2009), n.p.). 
Even at this early point in 'L'Ombre du double', the poet suspects that the outcome of his manipulations of the ombre of language will be the figurative, and ultimately literal, death of the writing 'je', survived and usurped by the 'tu' of his virtual, verbal double. The narrator of Le 19 octobre 1977 reflects on the literary tradition of the Doppelgänger in similar terms:

On dit que celui qui rencontre son double meurt ou devient fou; s'il survit et reste sain, il devient le plus que vivant. Mais si le plus que vivant raconte son histoire, il transforme son illumination en une chose nocturne, et son soleil devient un soleil d'en bas, un soleil noir. On dit aussi que certains fabriquent leur double pour voir; celui qui agit ainsi est un vivant mort, et sa vision le change en mort vivant.

Mais d'où viennent ces histoires, qui n'ont jamais couru la moindre bouche, et seulement de livre en livre? (p. 57) ${ }^{56}$

Applying these inversions to the 'je' of 'L'Ombre du double' would make him at once a 'plus que vivant' in real life, a 'vivant mort' as he writes the dark, inverted double, and a future 'mort vivant' in the afterlife of his text which has conjured the phantom into existence.

\section{Reading the 'ombre'}

Despite this, the poet has no choice but to renew his efforts to construct and confront the verbal 'ombre' of his 'double' in the specular text. The two terms are not in fact synonymous, for 'ombre' carries a marked temporal valency and associations with death, while 'double' stresses close spatial similarity as well as the mechanism of duplication. Mediated by the underlying figure of the dark mirror, these values play off each other in the textual space of 'L'Ombre du double', whose title now appears as a figural sablier in its own right, setting up multiple reflections and exchanges between reality, self, and language which will generate the text. A sablier of a subtle and productive type, because its twin terms are at once similar, creating an en abyme effect of infinite regression in the mirror (the writing self observes itself writing its own observation of its reflected double/shade...), and sufficiently distinct to sustain the exchange of meaning between the two vessels. This metapoetic significance is highlighted in a later text, 'Un jour de grâce' (2000), which opens Volume I of Bernard Noël's ongoing collected works. In a short 'P.-S.' the poet presents the themes of 'L'Ombre du double' as essential attributes of the writing process, and of our mental life itself:

Toute chose mentale a son arrière-pays qui se perd dans les ténèbres. L'écriture cherche à dialoguer avec la présence qui se tient là-bas, dans le noir. On a tendance à penser que ce là-bas est un au-delà alors qu'il est un en-deçà. Qu'il est du côté de l'insaisissable

${ }^{56}$ Compare, from 'Genèse de l'arbre' (1992): 'l'homme qui a connu son ombre | passe à travers lui-même vers sa mort' ( $R V$, pp. 115-52 (p. 143)). 
origine et non dans un après dont la porte serait la mort. Celui-qui-écrit-ici voit son ombre se dessiner vaguement, surgir, s'avancer, reculer, se perdre. Est-ce bien une ombre: n'est-ce pas plutôt son double? Le Je n'est rien tant qu'il ne s'est pas reflété sur le $\mathrm{Tu} . . .57$

The 'Tu' of a shadowy alter ego is located here, via familiar spatial and temporal sabliers, not in the projected depth of the mirror image ('au-delà') but in the space of the mind ('en-deçà), not in our past ('l'insaisissable origine') but our future ('la mort'). The presentness of writing demands engagement with these fluctuating dimensions of identity, as is stressed in Noël's own presentation of 'L'Ombre du double' on the back cover of the original (1993) edition:

Le reflet met dans l'air un semblable: un corps passé dans son après. Les mots mettent dans l'air une forme de même nature, mais leur fumée est invisible, sauf si on la souffle vers quelque surface que la nuit rend profonde. Le monde prononcé ici est alors vu là-bas...

Here, the sablier equivalence between forms in the dark mirror and those carried by language is mediated by a parallel syntactic construction ('met/mettent dans l'air') which implies a familiar equivalence between mirror-space, the mind ('l'air [de la tête]'), and the text itself; 'quelque surface' invites an inverted analogy between the dark mirror as photographic negative and the white page of the 'print' on which the poem materializes. The conceptual 'souffle' of words is an airy, monochromatic inversion of the dark mirror-shadows, but words themselves only become visible (develop), in a further reinversion, once 'breathed' onto the surface which divides the two spaces of the sablier, light mist on dark mirror, ${ }^{58}$ or black text on page. A further spatial construction ('ici'/'là-bas') then speaks of the reception of the text: once the poet has transferred his mental 'souffle' to the page in the 'fumée' of words, the 'ombre' of the poet's 'double' needs to be reactualized in a different mental space and time, by a different person.

In 'Le Passant de l'Athos' (1997) Noël restates this essential requirement with a nod to Mallarmé and another paradoxical sablier inversion:

[le poème] n'est tel qu'en lui-même que hors de lui devenu souffle en tête et buée verbale phénix d'air toujours naissant sur quelque lèvre

$$
(R V, \text { p. } 37)^{59}
$$

For the shadow-self carried by the poem ('en lui-même') to be resurrected externally ('hors de lui'), it must be verbalized ('souffle en tête et buée verbale')

57 Bernard Noël, Les Plumes d'Éros: CEuvres 1 (Paris: P.O.L., 2010), pp. 7-16 (p. 15).

${ }^{8}$ Compare 'la sueur du verre' (EC, p. 230), quoted above.

59 See the opening line of 'Tombeau d'Edgar Poe' (1887): 'Tel qu'en lui-même enfin l'éternité le change' (Stéphane Mallarmé, Poésies, ed. by Bertrand Marchal (Paris: Gallimard, 1992), p. 60). 
and respoken by a reader ('quelque lèvre', in parallel to 'quelque surface', above): only then can it overcome the silent interment to which writing condemns it-for 'le silence est terre d'air' (EC, p. 238):

Il faut faire un effort pour lire, pour regarder, pour aimer... Il faut faire un effort vers l'Autre. [. . .] Oui, le lecteur refait le livre. Le lecteur est un interprète... comme le musicien est un interprète. [...] on ne relit pas deux fois le même livre. (En présence..., p. 54$)^{60}$

The realization of the virtual poetic identity emerging from Noël's multiply inverted sablier requires work from the reader, an active (and, alluding to Heraclitus, constantly renewed) engagement with what we read. As the second 'Chemin de ronde' suggests, we are forced to flip and reinvent our own expectations of meaning to see through the conceptual 'buée' of words on the page:

Devant un tableau, une peinture, on regarde la beauté; devant une page, on est dans sa buée. Lire, c'est transmuer ce que disent les mots: faire un regard rempli de vie avec leur plomb grisâtre. (LS, p. 128)

Just as the poet transmutes his inner void into verbal matter, so the reader must transmute abstract words into a living, dialectical engagement with the poet's shadow-double in the fluctuating mirror of the text ('La lecture: effort de vision', observes Noël further down the same page). The essay on Gracq quoted above plays on the quasi-synonymy of 'visage' and 'figure' to hint at what this engagement with a particular writer's persona involves:

C'est-du-Gracq ne renvoie pas à Julien Gracq, mais à son double: un double qui, au lieu d'un visage, a des figures. (13C, p. 25)

Reading the poet's 'double' means working to understand his 'figures', and in this process the page/mirror acts as the constriction in the sablier, the point of intersection and communication between the mental spaces of writer and reader, through which the poetic exchange, phenomenological in its essence, takes place:

Si la phénoménologie m'attire, c'est peut-être qu'elle est le seul moyen d'intégrer le double. Je est un Autre, mais de cet Autre vu me revient un regard qui m'intensifie au lieu de me dissocier. ${ }^{61}$

The textual hourglass allows poet and reader not just to monitor the passage

60 Compare, in Noël's 1974 interview with Jean-Pierre Vélis: 'Le livre est une boîte qui n'existe que si on l'ouvre. Le livre n'est rien. C'est un objet mort que son lecteur anime. Autant de lecteurs, autant de lectures' (13C, pp. 99-104 (p. 100)). Also, 'Nous revoilà dans l'interminable, qui peut aussi s'écrire l'in-fini, et il invite chaque lecteur à défaire et à refaire. Si on impose un centre, on exclut [...] le lecteur de sa capacité créatrice. C’est la chance du poème de pouvoir être lu, réinterprété' (L'Espace du poème, p. 34).

61 'Le Chemin de Ronde I' (1958-63), LS, pp. 59-74 (p. 69). 
of time towards death, but to maintain a vigilant watch on the relational self in all its paradoxes. If, in the words of Alain Marc, 'l'œuvre de Bernard Noël figure parmi les plus belles et les plus hypnotiques, troublantes, des cinquante dernières années', it is perhaps because the 'immense remue-méninges [...] dans tous les domaines de l'humain, du sensible et de la littérature' ${ }^{62}$ into which his poetry draws the reader is articulated by highly original figures of phenomenological exchange, grounded in the early sablier. The perpetually reinvertible hourglass, which in 'L'Ombre du double' takes the organizing form of a dark mirror, constructs a multiply connected duality linking the 'espace de tête' of the poet to that of his reader, whose virtual portrait it therefore also constructs as s/he becomes, for a time, the poet's double:

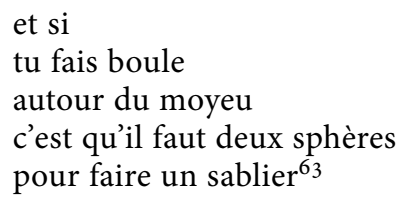

63 'La Nuit de Londres' (1970), EC, pp. 137-141 (p. 140). 